\title{
Synthesis, X-ray Structure, Conformational Analysis, and DFT Studies of a Giant s-Triazine bis-Schiff Base
}

\author{
Zainab M. Almarhoon ${ }^{1, * \mathbb{D}}$, Maha I. Al-Zaben ${ }^{1}$, Abir Ben Bacha ${ }^{2,3} \mathbb{D}$, Matti Haukka ${ }^{4} \mathbb{D}$, Ayman El-Faham ${ }^{5} \mathbb{D}$ \\ and Saied M. Soliman 5 ,*
}

1 Department of Chemistry, College of Science, King Saud University, P.O. Box 2455, Riyadh 11451, Saudi Arabia; mzaben@ksu.edu.sa

2 Biochemistry of Department, College of Sciences, King Saud University, P.O. Box 22452, Riyadh 11495, Saudi Arabia; aalghanouchi@ksu.edu.sa

3 Laboratory of Plant Biotechnology Applied to Crop Improvement, Faculty of Science of Sfax, University of Sfax, Sfax 3038, Tunisia

4 Department of Chemistry, University of Jyväskylä, FI-40014 Jyväskylä, Finland; matti.o.haukka@jyu.fi

5 Department of Chemistry, Faculty of Science, Alexandria University, P.O. Box 426, Ibrahimia, Alexandria 21321, Egypt; aymanel_faham@hotmail.com or ayman.elfaham@alexu.edu.eg

* Correspondence: zalmarhoon@ksu.edu.sa (Z.M.A.); saeed.soliman@alexu.edu.eg (S.M.S.); Tel.: +966-118055273 (Z.M.A.); +20-1111361059 (S.M.S.)

check for updates

Citation: Almarhoon, Z.M.; Al-Zaben, M.I.; Ben Bacha, A.; Haukka, M.; El-Faham, A.; Soliman, S.M. Synthesis, X-ray Structure, Conformational Analysis, and DFT Studies of a Giant $s$-Triazine bis-Schiff Base. Crystals 2021, 11, 1418. https:// doi.org/10.3390/cryst11111418

Academic Editors: Assem Barakat and Alexander S. Novikov

Received: 6 November 2021

Accepted: 16 November 2021

Published: 20 November 2021

Publisher's Note: MDPI stays neutral with regard to jurisdictional claims in published maps and institutional affiliations.

Copyright: (c) 2021 by the authors. Licensee MDPI, Basel, Switzerland. This article is an open access article distributed under the terms and conditions of the Creative Commons Attribution (CC BY) license (https:// creativecommons.org/licenses/by/ $4.0 /)$.
Abstract: The current work involves the synthesis of 2,2'-(6-(piperidin-1-yl)-1,3,5-triazine-2,4-diyl)bis (hydrazin-2-yl-1-ylidene))bis(methanylylidene))diphenol 4, characterization, and the DFT studies of the reported compound. The crystal unit cell parameters of 4 are $a=8.1139$ (2) $\AA, b=11.2637(2) \AA$, $\mathrm{c}=45.7836(8) \AA$. The unit cell volume is $4184.28(15) \AA^{3}$ and $\mathrm{Z}=4$. It crystallized in the orthorhombic crystal system and Pbca space group. The $\mathrm{O} \ldots \mathrm{H}, \mathrm{N} \ldots \mathrm{H}, \mathrm{C} \ldots \mathrm{H}, \mathrm{H} \ldots \mathrm{H}$ and $\mathrm{C} \ldots \mathrm{C}$ intermolecular contacts which affect the crystal stability were quantitatively analyzed using Hirshfeld calculations. Their percentages were calculated to be $9.8,15.8,23.7,46.4$, and $1.6 \%$ from the whole contacts occurred in the crystal, respectively. Conformational analysis was performed using DFT calculations for 17 suggested conformers and the most stable conformer was found to be the one which is stabilized by two intramolecular $\mathrm{O}-\mathrm{H} \ldots \mathrm{N}$ hydrogen bonding interactions. This conclusion was further revealed by natural bond orbital calculations.

Keywords: s-triazine; bis-Schiff base; conformational analysis; Hirshfeld analysis; NBO

\section{Introduction}

Given the effectual reactivity of TCT (cyanuric chloride, 2,4,6-trichlorotriazine) with a diversity of nucleophiles, it is regularly used in organic synthesis as template to access numerous molecular systems [1,2]. TCT is an important moiety due to its lower price, marketable availability, and the three chlorine atoms can be replaced in stepwise manner [1]. TCT derivatives were reported to have a broad range of biological activities [3]. Some new $s$-triazine based chalcones and their derivatives were found to work as potent antimicrobial, anti-cancer and anti-malarial agents [4-9].

On the other hand, Schiff bases of triazine derivatives are considered as extraordinary class of compounds. The two connected nitrogen atoms $(-\mathrm{CH}=\mathrm{N}-\mathrm{N}-)$ are of distinct nature and the $\mathrm{C}=\mathrm{N}$ that is conjugated with a lone pair of the second nitrogen are responsible for their properties [10-16]. This family of compounds are regularly used as polydentate chelating agents that form a diversity of complexes with a range of different metals [17-19]. Enormous hydrazones derivatives and their complexes have been used in several applications, such as metal-ions extraction and microdetermination of metal-ion [20]. Moreover, their biological activities have been reported in literatures [21-25]. Many synthesized s-triazine hydrazone derivatives were reported and explored with superior interest in 
supramolecular and coordination chemistry [26,27], material chemistry [28], and complexation with several metal-ions [29-33].

It is well known that the s-triazine bis-Schiff base compounds could exist in two main structures which are shown in Figure 1. In view of the interesting importance and the diverse structural features of this class of $s$-triazine based compounds, the present work presents the synthesis, characterization, $\mathrm{X}$-ray single crystal structure investigations combined with Hirshfeld and DFT calculations of a novel giant s-triazine based Schiff base (4). Relative stability of 17 suggested conformers of 4 were also investigated.<smiles>[R]C=NNc1nc(NN=C[R])nc(N2CCCCC2)n1</smiles>

Form 1<smiles>c1ccncc1</smiles>

Pyridine (py) Pyrimidine (pym)<smiles>c1cncnc1</smiles>
R (a)

.
(1)

Figure 1. The general structure of $s$-triazine bis-Schiff base.

\section{Materials and Methods}

Chemicals were purchased from Sigma-Aldrich Company (Chemie GmbH, 82024 Taufkirchen, Germany). Perkin-Elmer 2400 instrument (PerkinElmer, Inc., 940 Winter Street, Waltham, MA, USA) was used for CHN analyses.

\subsection{Synthesis of 2,2'-(6-(piperidin-1-yl)-1,3,5-triazine-2,4-diyl)bis(hydrazin-2 -yl-1-ylidene))bis(methanylylidene))diphenol; 4}

2,4-Dihydrazinyl-6-(piperidin-1-yl)-1,3,5-triazine (10 mmoles) was added portionwise to a hot solution of 2-hydroxybenzaldehyde (10 mmoles) in ethanol (100 mL) containing acetic acid (2-3 drops; Scheme 1). After complete addition, the reaction was heated under reflux for $6 \mathrm{~h}$ and then was left cooling at room temperature and then filter the pure paleyellow solid (the complete reaction was followed by TLC (ethyl acetate-hexane 2:1). The product was left to dry and then recrystallized from ethanol. Yield 95\%; mp 263-265 ${ }^{\circ} \mathrm{C}$; ${ }^{1} \mathrm{H}$ NMR (DMSO-d $): \delta=1.52$ (brs, 4H, 2CH ), 1.63 (brs, 2H, $\mathrm{CH}_{2}$ ), 3.80 (brs, 2H, $\mathrm{CH}_{2}$ ), 6.87-6.95 (m, 4H, Ar), 7.37-7.41 (m, 2H, Ar), 7.21-7.26 (m, 2H, Ar), 8.29 (s, 2H,CH=N), 11.20 (brs, 2H, NH), 12.15 (brs, 2H, OH) ppm; ${ }^{13} \mathrm{C}$ NMR (DMSO-d $\left.d_{6}\right): \delta=24.3,25.6,43.6,116.1$, $118.9,130.3,143.9,157.4,162.8,164.2$ ppm; Anal. Calc. for $\mathrm{C}_{22} \mathrm{H}_{24} \mathrm{~N}_{8} \mathrm{O}_{2}$ (432.49 g/mol): C, 61.10; H, 5.59; N, 25.91. Found: C, 61.23; H, 6.61; N, 25.74.

\subsection{X-ray Structure Determinations}

The crystal of 4 was immersed in cryo-oil, mounted in a loop at $120 \mathrm{~K}$, and the data were collected on a Rigaku Oxford Diffraction Supernova diffractometer using $\mathrm{Cu} \mathrm{K} \alpha$ radiation. The CrysAlisPro(v.1.171.40.67a) [34] software package was used for cell refinement and data reduction. A gaussian absorption correction (CrysAlisPro [34]) was applied to the intensities before structure solution. The structure was solved by intrinsic phasing (SHELXT [35]) method. Structural refinement was carried out using SHELXL(2018/3) [36] software with SHELXLE [37] graphical user interface. The $\mathrm{NH}$ and $\mathrm{OH}$ hydrogen atoms were located from the difference Fourier map and refined isotropically. All other hydrogen atoms were positioned geometrically and constrained to ride on their parent atoms, with $\mathrm{C}-\mathrm{H}=0.95-0.99 \AA$ and $\mathrm{U}_{\text {iso }}=1.2 \cdot \mathrm{U}_{\text {eq }}$ (parent atom). The CIF data are given in details in Supplementary data and crystal structure measurement and refinments details are summarized in Table 1. Crystal Explorer 17.5 program [38] was used for Hirshfeld surface analysis. 
<smiles>Clc1nc(Cl)nc(Cl)n1</smiles>

TCT; 1 i) Piperdine Acetone-water $0-5^{\circ} \mathrm{C} 2 \mathrm{~h}$

ii) Hydrazine hydrate (80\%) ethanol refl. 6-8h<smiles>NNc1nc(NN)nc(N2CCCCC2)n1</smiles><smiles>O=Cc1ccccc1O</smiles>

2 ethanol-2 drops $\mathrm{AcOH}$ refl. $6 \mathrm{~h}$<smiles>Oc1ccccc1/C=N\Nc1nc(N/N=C\c2ccccc2O)nc(N2CCCCC2)n1</smiles>

Scheme 1. Synthesis of 4 .

Table 1. Crystal Data of 4.

\begin{tabular}{|c|c|}
\hline CCDC & 2118553 \\
\hline empirical formula & $\mathrm{C}_{22} \mathrm{H}_{24} \mathrm{~N}_{8} \mathrm{O}_{2}$ \\
\hline Fw & 432.49 \\
\hline temp $(\mathrm{K})$ & $120(2)$ \\
\hline$\lambda(\AA)$ & 1.54184 \\
\hline Crystal system & Orthorhombic \\
\hline space group & Pbca \\
\hline $\mathrm{a}(\AA)$ & $8.1139(2)$ \\
\hline $\mathrm{b}(\AA)$ & $11.2637(2)$ \\
\hline$c(\AA)$ & $45.7836(8)$ \\
\hline$V\left(\AA^{3}\right)$ & $4184.28(15)$ \\
\hline $\mathrm{Z}^{12}$ & 8 \\
\hline$\rho_{\text {calc }}\left(\mathrm{Mg} / \mathrm{m}^{3}\right)$ & 1.373 \\
\hline$\mu(\mathrm{Mo} \mathrm{K} \alpha)\left(\mathrm{mm}^{-1}\right)$ & 0.762 \\
\hline No. reflns. & 29,199 \\
\hline Unique reflns. & 4404 \\
\hline Completeness to $\theta=67.684^{\circ}$ & $99.9 \%$ \\
\hline $\operatorname{GOOF}\left(F^{2}\right)$ & 1.047 \\
\hline $\mathrm{R}_{\text {int }}$ & 0.0345 \\
\hline $\mathrm{R} 1^{\mathrm{a}}(\mathrm{I} \geq 2 \sigma)$ & 0.0374 \\
\hline $\mathrm{wR} 2{ }^{\mathrm{b}}(\overline{\mathrm{I}} \geq 2 \sigma)$ & 0.0911 \\
\hline
\end{tabular}

\section{Computational Details}

Density functional calculations (DFT) at the B3LYP method and using 6-31G(d,p) basis sets were performed to optimize the molecular structure of the suggested 17 conformers of the studied s-triazine bis-Schiff base (Figure 2). For this task, Gaussian 09 package was used $[39,40]$. All optimized structures are local minimum as indicated from the absence of any imaginary vibrational mode. The calculated energies and thermodynamic 
parameters of the suggested conformers were used to predict the most stable form. NBO 3.1 program [41] was used for natural bond orbital analysis.

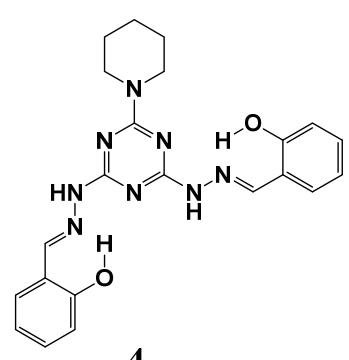

4

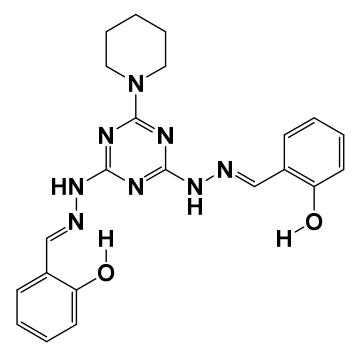

4D<smiles>Oc1ccccc1/C=N/Nc1nc(N/N=C/c2ccccc2O)nc(N2CCCCC2)n1</smiles>

4A<smiles>Oc1ccccc1/C=N/Nc1nc(N/N=C/c2ccccc2O)nc(N2CCCCC2)n1</smiles>

4B<smiles>Oc1ccccc1/C=N/Nc1nc(N/N=C/c2ccccc2O)nc(N2CCCCC2)n1</smiles>

4C<smiles>Oc1ccccc1/C=N/Nc1nc(N/N=C/c2ccccc2O)nc(N2CCCCC2)n1</smiles>

$4 \mathbf{E}$<smiles>Oc1ccccc1/C=N/NNc1nc(N/N=C/c2ccccc2O)nc(N/N=C/c2ccccc2O)n1</smiles>

4F<smiles>Oc1ccccc1/C=N/Nc1nc(N/N=C/c2ccccc2O)nc(N2CCCCC2)n1</smiles><smiles>Oc1ccccc1/C=N/Nc1nc(N/N=C/c2ccccc2O)nc(N2CCCCC2)n1</smiles>

$4 I$

4J<smiles>Oc1ccccc1/C=N/Nc1nc(N/N=C/c2ccccc2O)nc(N2CCCCC2)n1</smiles>

$4 K$<smiles>Oc1ccccc1/C=N/Nc1nc(N/N=C/c2ccccc2O)nc(N2CCCCC2)n1</smiles>

3L

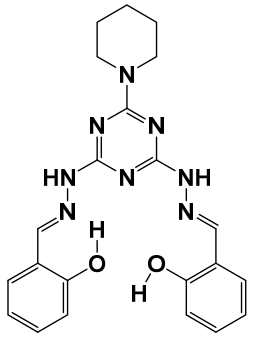

4M

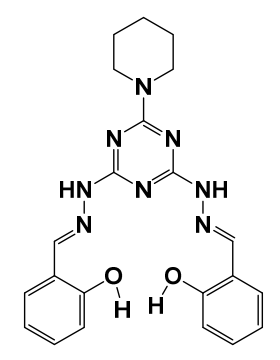

$4 N$<smiles>Oc1ccccc1C=NNc1nc(NN=Cc2ccccc2O)nc(N2CCCCC2)n1</smiles>

40<smiles>Oc1ccccc1/C=N/Nc1nc(N/N=C/c2ccccc2O)nc(N2CCCCC2)n1</smiles>

4P

Figure 2. The suggested conformers of the s-triazine bis-Schiff base; 4 . 


\section{Results and Discussion}

\subsection{Crystal Structure Description}

The X-ray structure of 4 is shown in Figure 3. The compound crystallized in the orthorhombic crystal system and Pbca space group with unit cell parameters of a $=8.1139(2) \AA$, $\mathrm{b}=11.2637(2) \AA, \mathrm{c}=45.7836(8) \AA$, and unit cell volume of $4184.28(15) \AA^{3}$ while $\mathrm{Z}=4$. Some bond distances and angles are depicted in Table 2.

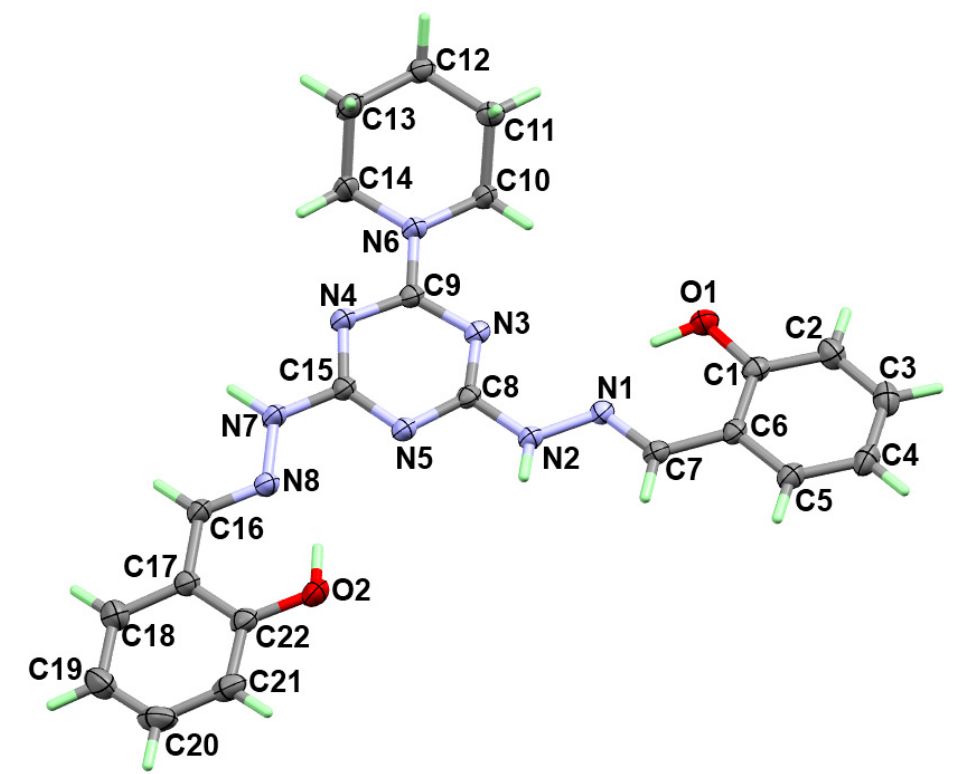

Figure 3. X-ray structure with thermal ellipsoids at 50\% probability level for 4 .

Table 2. Selected bond lengths $[\AA]$ and angles $\left[{ }^{\circ}\right]$ for 4 .

\begin{tabular}{cccc}
\hline Atoms & Distance & Atoms & Distance \\
\hline O1-C1 & $1.3578(14)$ & N4-C9 & $1.3477(15)$ \\
O2-C22 & $1.3624(16)$ & N5-C15 & $1.3379(15)$ \\
N1-C7 & $1.2882(15)$ & N5-C8 & $1.3445(15)$ \\
N1-N2 & $1.3697(13)$ & N6-C9 & $1.3493(15)$ \\
N2-C8 & $1.3691(15)$ & N6-C10 & $1.4657(15)$ \\
N3-C8 & $1.3291(15)$ & N6-C14 & $1.4707(15)$ \\
N3-C9 & $1.3622(15)$ & N7-C15 & $1.3565(15)$ \\
N4-C15 & $1.3394(15)$ & N7-N8 & $1.3622(14)$ \\
Atoms & Angle & Atoms & Angle \\
C7-N1-N2 & $116.50(10)$ & C10-N6-C14 & $114.56(10)$ \\
C8-N2-N1 & $121.50(10)$ & C15-N7-N8 & $120.60(10)$ \\
C8-N3-C9 & $113.29(10)$ & C16-N8-N7 & $117.41(10)$ \\
C15-N4-C9 & $113.93(10)$ & O1-C1-C2 & $118.15(11)$ \\
C15-N5-C8 & $112.03(10)$ & O1-C1-C6 & $121.81(11)$ \\
C9-N6-C10 & $122.81(10)$ & C2-C1-C6 & $120.03(11)$ \\
C9-N6-C14 & $121.91(10)$ & C3-C2-C1 & $120.06(12)$ \\
\hline
\end{tabular}

It is well known that the s-triazine bis-Schiff base compounds could exist in two main structures which are shown in Figure 1. The solid-state structure of 4 indicated that the conformation of the two hydrazine arms are quite different and exists in Form 2 rather than Form 1. A main reason for the extrastability of Form 2 is the less steric among the salicylidene moieties. In Form 1, strong repulsion between the two salicylidene arms makes this option is not sterically favored situation.

In addition, this molecular conformation of the bis-Schiff base s-triazine is found stabilized by two strong intramolecular $\mathrm{O}-\mathrm{H}$... N hydrogen bonding interactions between the $\mathrm{OH}$ group of the salicylidene moiety acting as hydrogen bond donor with the nitrogen 
atom of the azomethine group as a hydrogen bond acceptor. The donor-acceptor distances are 2.648(3) and 2.608(1) $\AA$ for the O1-H1...N1 and O2-H2...N8 intramolecular O-H ... $\mathrm{N}$ hydrogen bonds, respectively. Additionally, there are two weak intramolecular $\mathrm{C}-\mathrm{H}$ ... N hydrogen bonds which are C10-H10B...N3 and C14-H14A...N4 with donor-acceptor distances of 2.785(2) and 2.746(2) $\AA$, respectively. More details regarding the hydrogen bond parameters are listed in Table 3 . The intramolecular hydrogen bonding interactions are presented as turquoise dotted lines in the upper part of Figure 4, while the red dotted lines represent the intermolecular hydrogen bonding interactions.

Table 3. Hydrogen bonds for $4\left[\AA\right.$ and $\left.^{\circ}\right]$.

\begin{tabular}{ccccc}
\hline D-H...A & $\mathbf{d}(\mathbf{D}-\mathbf{H})$ & $\mathbf{d}(\mathbf{H} . . . \mathbf{A})$ & $\mathbf{d}(\mathbf{D} \ldots \mathbf{A})$ & $<$ (DHA) \\
\hline O1-H1...N1 & $0.958(2)$ & $1.789(2)$ & $2.648(1)$ & $147.6(2)$ \\
O2-H2...N8 & $0.92(2)$ & $1.80(2)$ & $2.608(1)$ & $145.0(2)$ \\
N7-H7...O2 ${ }^{\text {i }}$ & $0.927(2)$ & $1.996(2)$ & $2.918(1)$ & $173.9(2)$ \\
C7-H7A...N3 ${ }^{\text {ii }}$ & 0.95 & 2.61 & $3.494(1)$ & 155.0 \\
C10-H10B...N3 & 0.99 & 2.35 & $2.7846(15)$ & 106.0 \\
C12-H12B...O1 iii & 0.99 & 2.57 & $3.2842(15)$ & 129.0 \\
C14-H14A...N4 & 0.99 & 2.29 & $2.7459(16)$ & 107.0 \\
C20-H20...N5 ${ }^{\text {iv }}$ & 0.95 & 2.52 & $3.4165(18)$ & 158.0 \\
\hline
\end{tabular}

${ }^{\mathrm{i}} 1 / 2-\mathrm{x}, 1 / 2+\mathrm{y}, \mathrm{z} ;{ }^{\text {ii }} 1 / 2-\mathrm{x},-1 / 2+\mathrm{y}, \mathrm{z} ;{ }^{\text {iii }} 3 / 2-\mathrm{x}, 1 / 2+\mathrm{y}, \mathrm{z}$ and ${ }^{\text {iv }}-1 / 2+\mathrm{x}, 1 / 2-\mathrm{y}, 1-\mathrm{z}$.
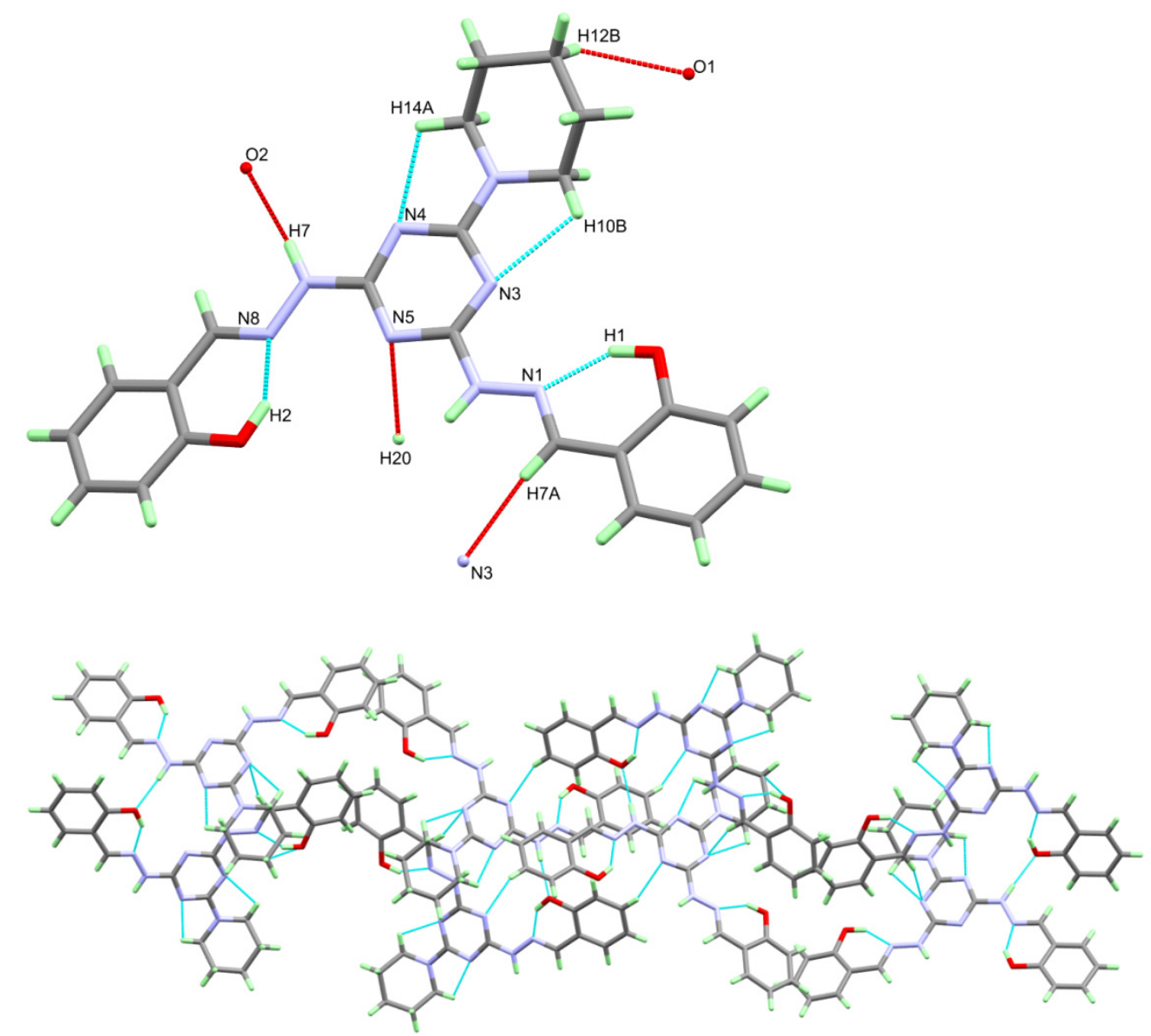

Figure 4. Hydrogen bond contacts (upper) and molecular packing (lower) of 4 .

The supramolecular structure of 4 is controlled by strong N7-H7...O2 hydrogen bonding interaction with a hydrogen-acceptor distance of 1.996(2) $\AA$ and donor-acceptor distance of 2.918(1) $\AA$. In addition, the molecules are further connected by weak C-H...O interactions (Table 3). Presentation of the molecular packing is given in Figure 4 (lower part). 


\subsection{Analysis of Molecular Packing}

The Hirshfeld surfaces of 4 are shown in Figure 5. The most important contacts having interaction distances shorter than the van der Waals ( $\mathrm{vdW}$ ) radii sum of the two interacting atoms are labeled $\mathrm{A}$ to $\mathrm{E}$ in the $\mathrm{d}_{\text {norm }}$ map. The $\mathrm{O} \ldots \mathrm{H}, \mathrm{N} \ldots \mathrm{H}, \mathrm{C} \ldots \mathrm{H}, \mathrm{H} \ldots \mathrm{H}$, and C ... C contacts are the most important in the crystal stability. The interaction distances obtained from the Hirshfeld calculations are depicted in Table 4 .
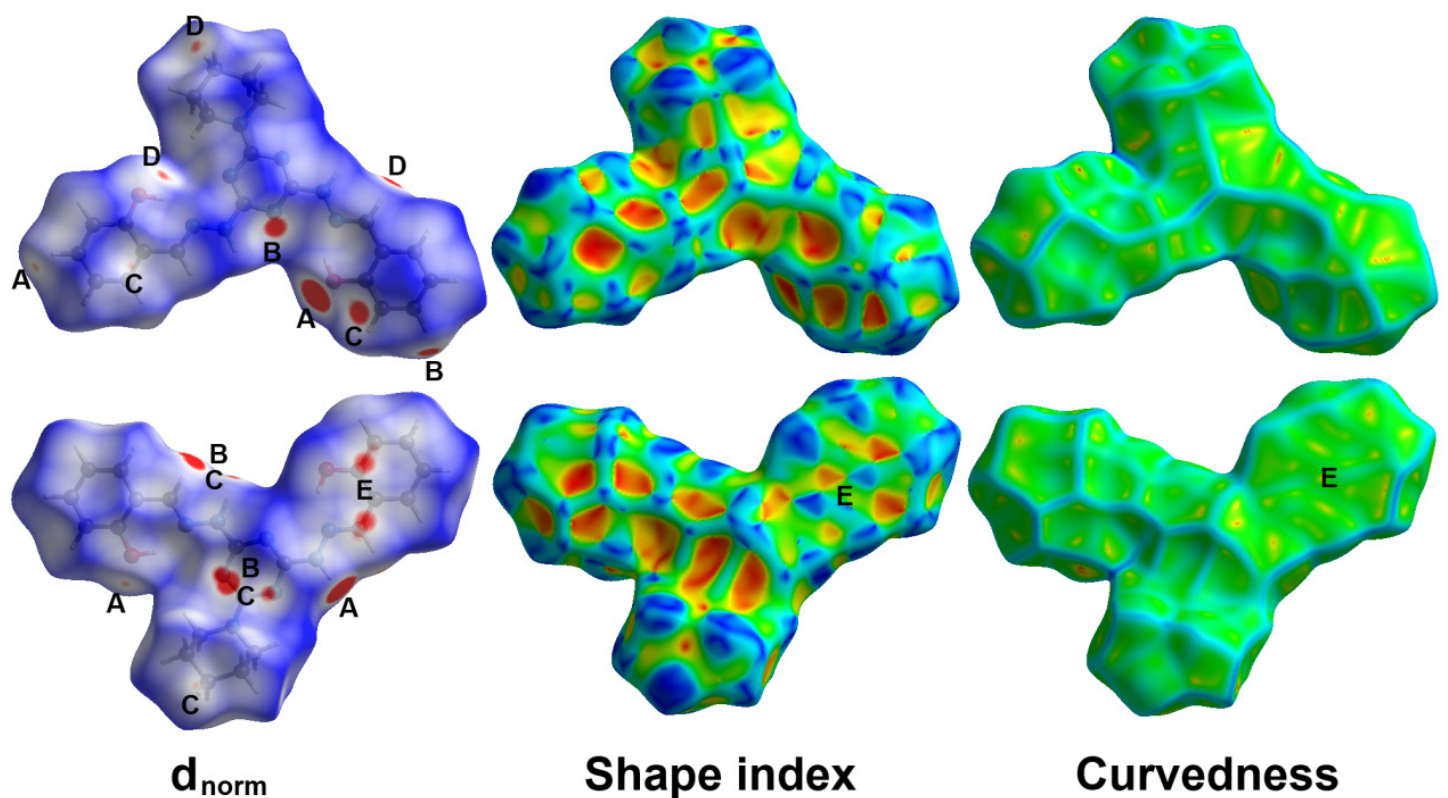

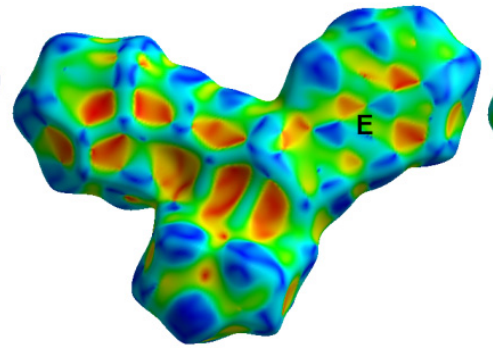

Shape index

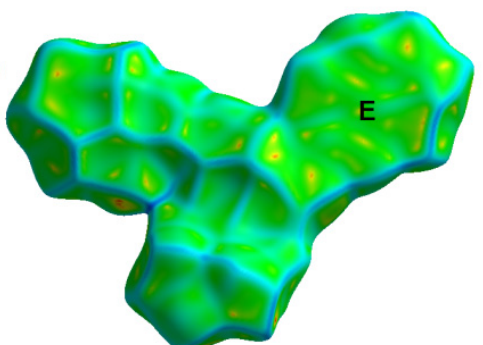

Curvedness

Figure 5. The $d_{\text {norm }}$ maps for the important interactions in 4. A: O .. H, B: N . . H; C: H . C ; D: H .. H, and E: C .. C contacts.

Table 4. Intermolecular interactions in 4.

\begin{tabular}{|c|c|c|c|}
\hline Contact & Distance & Contact & Distance \\
\hline $\mathrm{H} 12 \mathrm{~A} \ldots \mathrm{C} 5$ & 2.747 & $\mathrm{H} 2 \mathrm{~A} \ldots \mathrm{N} 4$ & 2.522 \\
\hline H7A . . C 9 & 2.499 & H7A ... N3 & 2.488 \\
\hline H7A . . . C9 & 2.494 & $\mathrm{H} 20 \ldots$ N5 & 2.394 \\
\hline $\mathrm{H} 16 \ldots$ C22 & 2.756 & $\mathrm{O} 2 \ldots \mathrm{H} 7$ & 1.914 \\
\hline H15 . . C21 & 2.509 & O1 ... H3 & 2.533 \\
\hline C16 . . C21 & 3.348 & H1 ... H12B & 2.155 \\
\hline $\mathrm{C} 16 \ldots \mathrm{C} 22$ & 3.235 & $\mathrm{H} 21 \ldots \mathrm{H} 16$ & $2.294^{\mathrm{a}}$ \\
\hline
\end{tabular}

${ }^{a}$ longer distances compared to the vdWs radii sum.

The percentage contributions for all possible interactions in the crystal are presented graphically in Figure 6. The $\mathrm{O} \ldots \mathrm{H}, \mathrm{N} \ldots \mathrm{H}, \mathrm{C} \ldots \mathrm{H}, \mathrm{H} \ldots \mathrm{H}$ and $\mathrm{C} \ldots \mathrm{C}$ contributed by $9.8,15.8,23.7,46.4$, and $1.6 \%$ from the whole fingerprint area, respectively. As can be seen from Figure 5 , all these interactions appeared as red colour regions in the $d_{\text {norm }}$ where the contact distances are shorter than vdW sum of the interacting atoms.

In addition, the decomposed fingerprint plot gave good indication on the importance of these contacts (Figure 7). For example, the $\mathrm{O} \ldots \mathrm{H}$ interactions appeared as very sharp spikes indicating strong interactions. The presence of some short C . . C contacts as red spots in the $d_{\text {norm }}$ with red/blue triangle in the shape index and flat green area in curvedness map revealed very well the presence of $\pi-\pi$ stacking interactions. The shortest C . . C contacts are C16 . . C21 (3.348 ̊) and C16 . . C22 (3.235 A). 


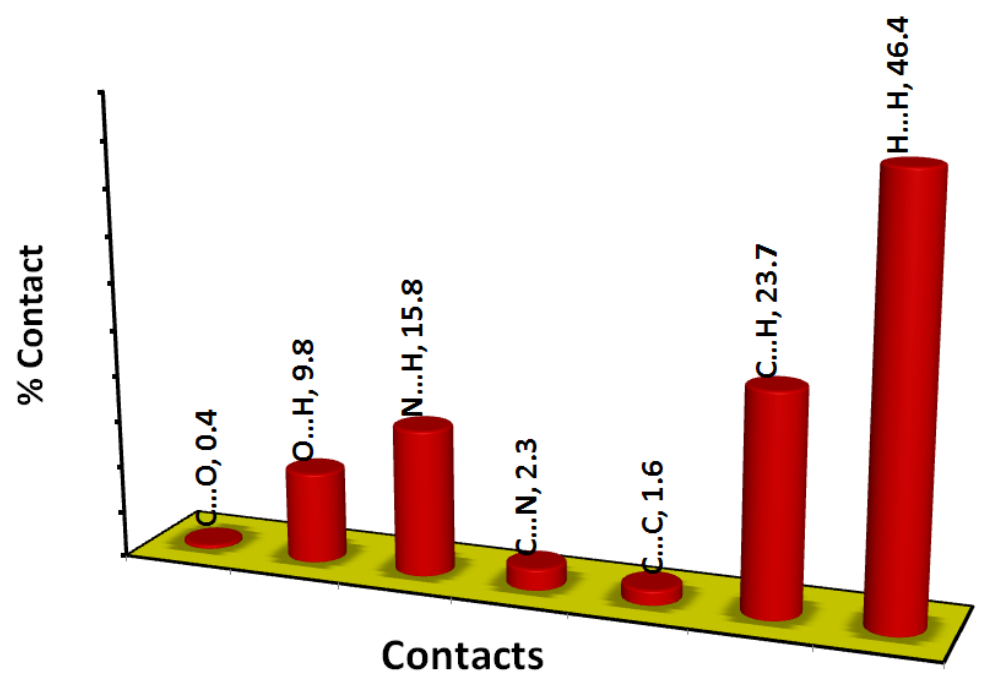

Figure 6. Intermolecular interactions and their percentages in 4.
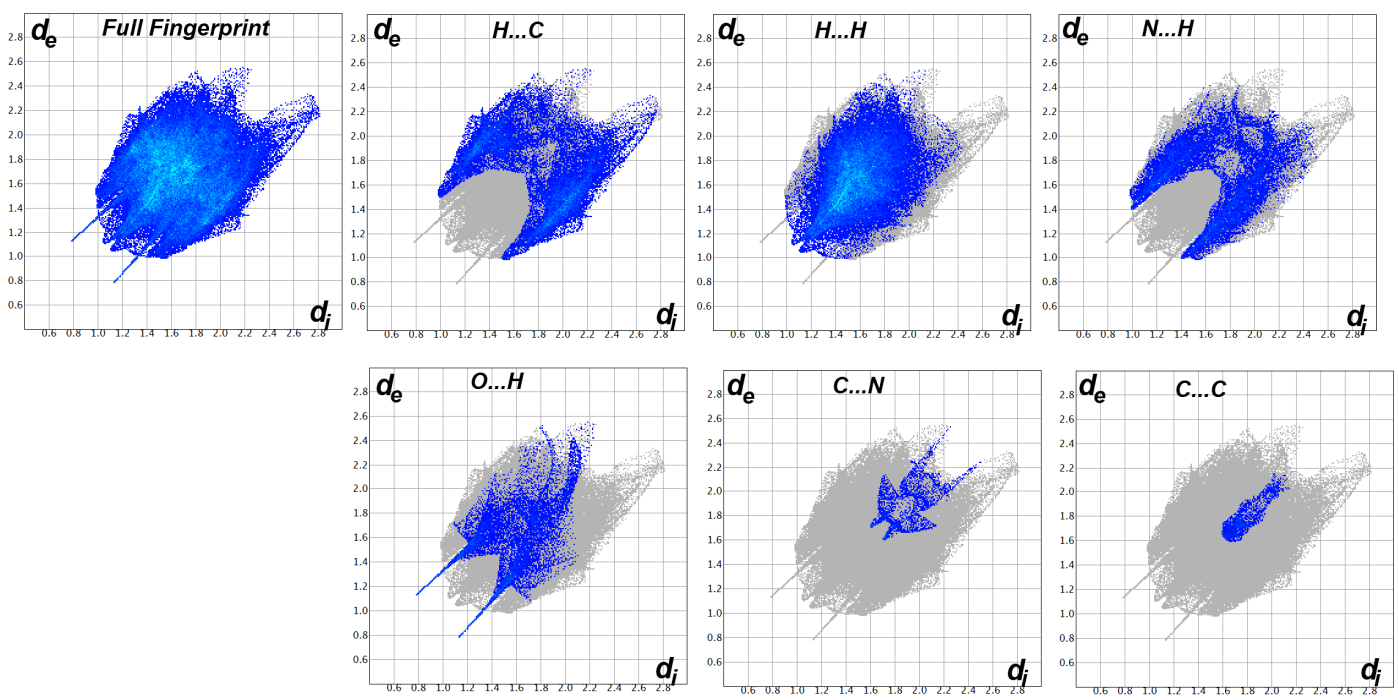

Figure 7. Full and decomposed fingerprint plots for the important interactions in 4.

\subsection{Conformational Analysis}

The structure of the 17 suggested conformers were calculated and the optimized geometries are shown in Figure 8. The total energies and thermodynamic parameters of the of the studied s-triazine bis-Schiff base are depicted in Table 5. The results indicated that conformer $\mathbf{4}$ is the most stable thermodynamically as this conformer has the lowest energy among the studied conformers which is found in accord with the reported X-ray structure of this compound. The second and third most stable conformers are $4 \mathrm{I}$ and $4 \mathrm{~L}$, respectively. These conformers are energetically higher than the most stable one by only 0.2951 and $2.2345 \mathrm{kcal} / \mathrm{mol}$, respectively. A clear common reason for the extrastabilty of these three conformers is the presence of two intramolecular $\mathrm{O}-\mathrm{H} \ldots \mathrm{N}$ hydrogen bonds in the three structures (Figure 8). On the other hand, some of the other conformers showed one intramolecular $\mathrm{O}-\mathrm{H} \ldots \mathrm{N}$ hydrogen while the others did not show any intramolecular $\mathrm{O}-\mathrm{H} \ldots \mathrm{N}$ hydrogen bond. The conformers $4 \mathrm{~B}, 4 \mathrm{~K}$, and $4 \mathrm{~N}$ were the highest energetically as these conformers did not comprise any intramolecular $\mathrm{O}-\mathrm{H}$... N hydrogen bond. The relative energies of the studied conformers are presented graphically in Figure 9. 


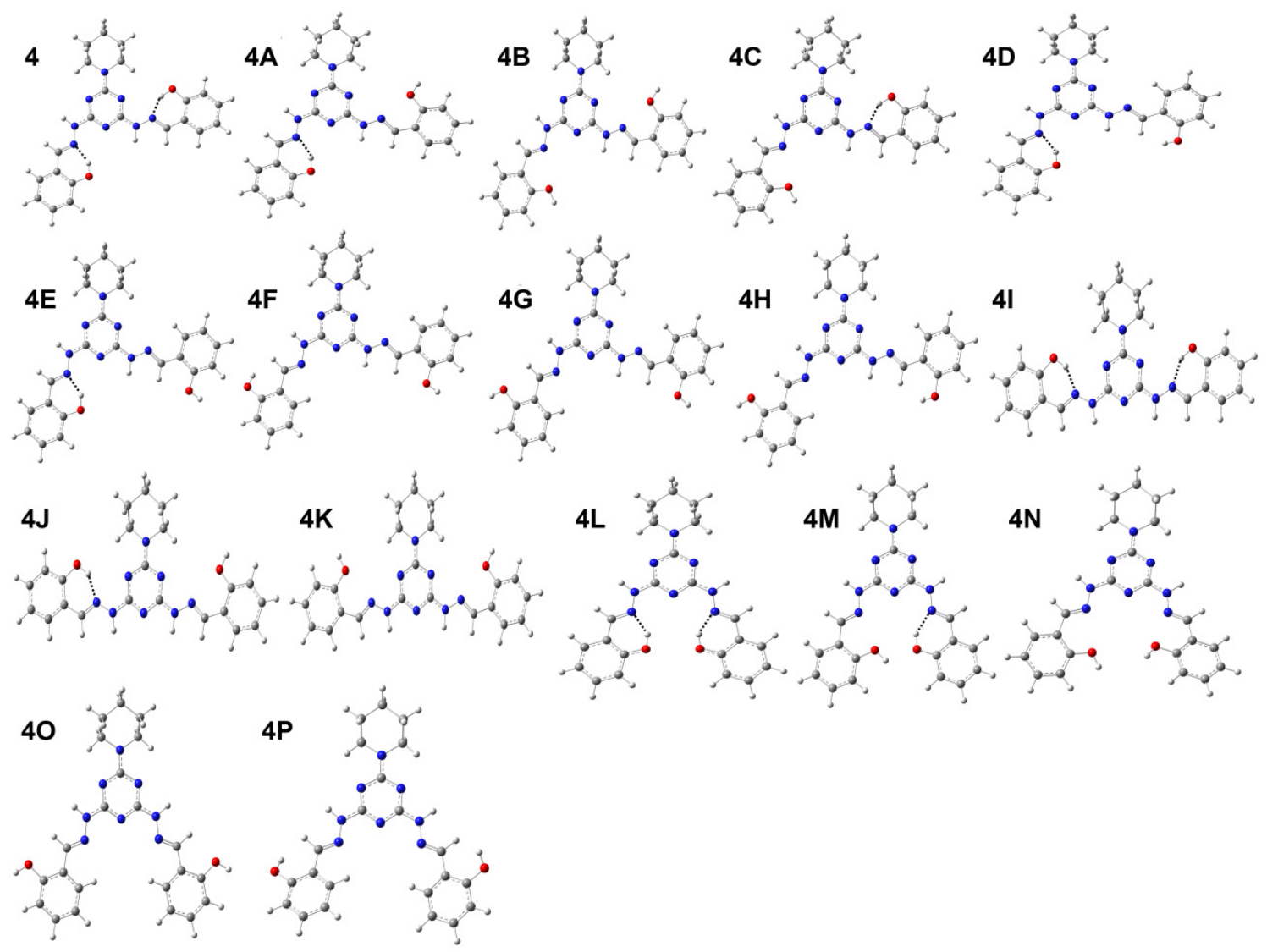

Figure 8. The optimized geometries of the suggested conformers of 4 . The intramolecular O-H ... N hydrogen bonds are presented by black dotted line.

Table 5. The calculated energies and thermodynamic properties of the studied conformers.

\begin{tabular}{|c|c|c|c|c|c|c|c|c|c|}
\hline Param. & 4 & $4 \mathrm{~A}$ & $4 B$ & $4 C$ & 4D & $4 \mathrm{E}$ & $4 F$ & $4 G$ & $4 \mathrm{H}$ \\
\hline$E^{a}$ & -1441.3046 & -1441.2844 & -1441.2635 & -1441.2841 & -1441.286847 & -1441.290592 & -1441.272653 & -1441.276378 & -1441.272801 \\
\hline ZPVE $^{a}$ & 0.4535 & 0.4526 & 0.4517 & 0.4525 & 0.452338 & 0.452615 & 0.451841 & 0.452084 & 0.451863 \\
\hline $\mathrm{E}_{\text {tot }} \mathrm{a}^{\mathrm{a}}$ & -1440.8511 & -1440.8318 & -1440.8118 & -1440.8316 & -1440.8345 & -1440.8380 & -1440.8208 & -1440.8243 & -1440.8209 \\
\hline$\Delta \mathrm{E}^{\mathrm{b}}$ & 0.0000 & 12.0882 & 24.6525 & 12.2360 & 10.4044 & 8.2278 & 18.9990 & 16.8140 & 18.9203 \\
\hline $\mathrm{H}^{\mathrm{a}}$ & -1440.8229 & -1440.8031 & -1440.7827 & -1440.8029 & -1440.805625 & -1440.80919 & -1440.791531 & -1440.795082 & -1440.791662 \\
\hline$\Delta \mathrm{H}^{\mathrm{b}}$ & 0.0000 & 12.3787 & 25.2167 & 12.5274 & 10.8118 & 8.5748 & 19.6558 & 17.4276 & 19.5736 \\
\hline $\mathrm{G}^{\mathrm{a}}$ & -1440.9125 & -1440.8946 & -1440.8756 & -1440.8942 & -1440.897779 & -1440.900977 & -1440.884482 & -1440.887956 & -1440.884582 \\
\hline$\Delta \mathrm{G}^{\mathrm{b}}$ & 0.0000 & 11.2197 & 23.1635 & 11.4368 & 9.2211 & 7.2144 & 17.5650 & 15.3850 & 17.5022 \\
\hline$S^{c}$ & 188.6180 & 192.5080 & 195.5080 & 192.2760 & 193.953 & 193.183 & 195.632 & 195.469 & 195.568 \\
\hline & $4 I$ & $4 \mathrm{~J}$ & $4 K$ & $4 \mathrm{~L}$ & $4 \mathrm{M}$ & $4 N$ & 40 & $4 P$ & \\
\hline $\mathrm{E}^{\mathrm{a}}$ & -1441.3044 & -1441.2844 & -1441.2638 & -1441.3010 & -1441.2878 & -1441.2597 & -1441.2747 & -1441.2672 & \\
\hline $\mathrm{ZPVE}^{\mathrm{a}}$ & 0.4538 & 0.4526 & 0.4518 & 0.4534 & 0.4526 & 0.4515 & 0.4521 & 0.4516 & \\
\hline $\mathrm{E}_{\text {tot }}{ }^{\mathrm{a}}$ & -1440.8506 & -1440.8318 & -1440.8120 & -1440.8475 & -1440.8353 & -1440.8081 & -1440.8227 & -1440.8156 & \\
\hline$\Delta \mathrm{E}^{\mathrm{b}}$ & 0.2951 & 12.1058 & 24.5161 & 2.2345 & 9.9103 & 26.9448 & 17.8395 & 22.2519 & \\
\hline $\mathrm{H}^{\mathrm{a}}$ & -1440.8228 & -1440.8031 & -1440.7830 & -1440.8192 & -1440.8069 & -1440.7790 & -1440.7935 & -1440.7863 & \\
\hline$\Delta \mathrm{H}^{\mathrm{b}}$ & 0.0201 & 12.3743 & 25.0285 & 2.2916 & 10.0362 & 27.5096 & 18.4359 & 22.9514 & \\
\hline$G^{a}$ & -1440.9125 & -1440.8939 & -1440.8750 & -1440.9093 & -1440.8955 & -1440.8715 & -1440.8856 & -1440.8790 & \\
\hline$\Delta \mathrm{G}^{\mathrm{b}}$ & 0.0094 & 11.6414 & 23.5444 & 1.9785 & 10.6518 & 25.7024 & 16.8559 & 21.0106 & \\
\hline$S^{c}$ & 188.6540 & 191.0780 & 193.5960 & 189.6690 & 186.5540 & 194.6810 & 193.9180 & 195.1290 & \\
\hline
\end{tabular}

${ }^{\mathrm{a}}$ A.U. ${ }^{\mathrm{b}} \mathrm{kcal} / \mathrm{mol}^{\mathrm{c}} \mathrm{Cal} / \mathrm{Mol} . \mathrm{K}$. 


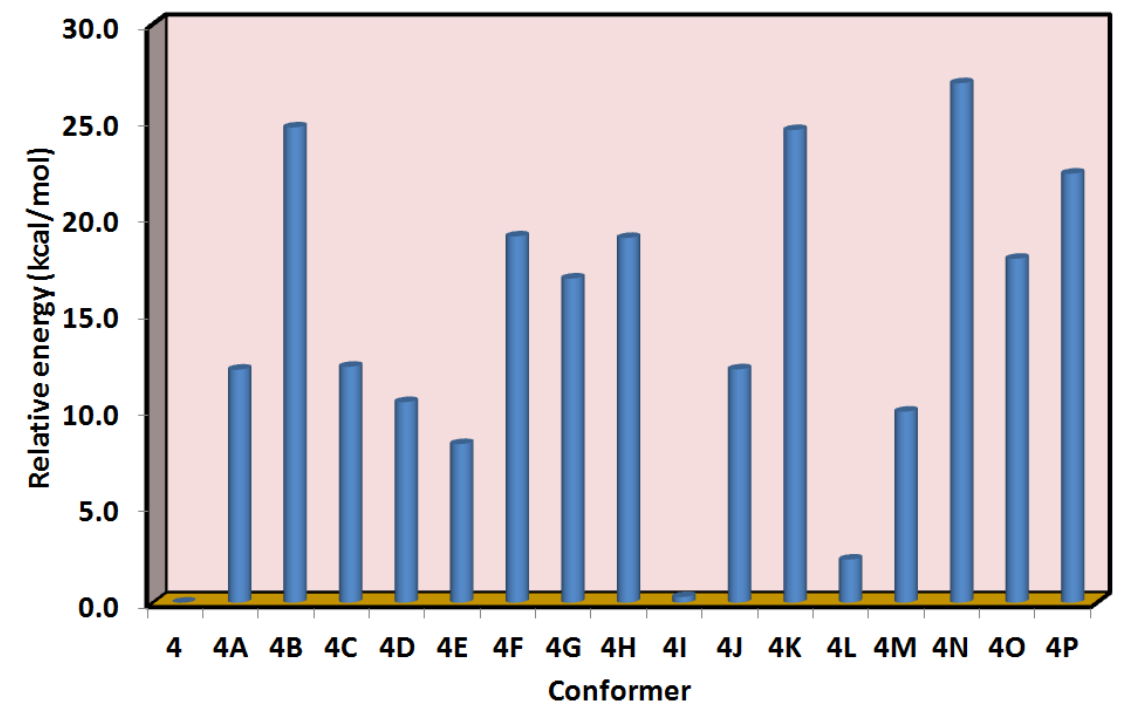

Figure 9. Relative energy of the suggested conformers of 4 compared to the most stable one.

\subsection{Optimized Geometry}

The calculated structure of 4 is shown in Figure 10. Few differences between the experimental and optimized structures were detected where the deviations in bond distances not exceed $0.02 \AA$ (Table S1; Supplementary Data). These deviations could be attributed to the crystal packing effects. Generally, there are good correlations between the calculated bond angles and distances with the experimental measurements (Figure 11).
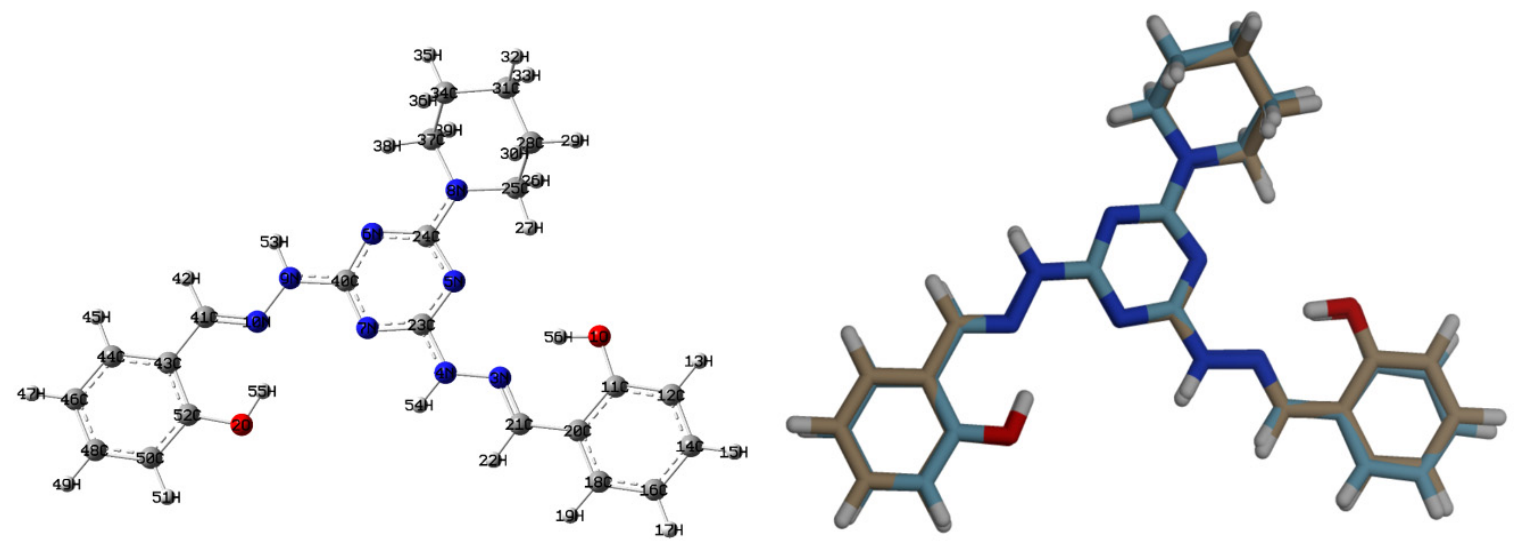

Figure 10. The calculated structure (left) of 4 and its overlay with the experimental one (right).
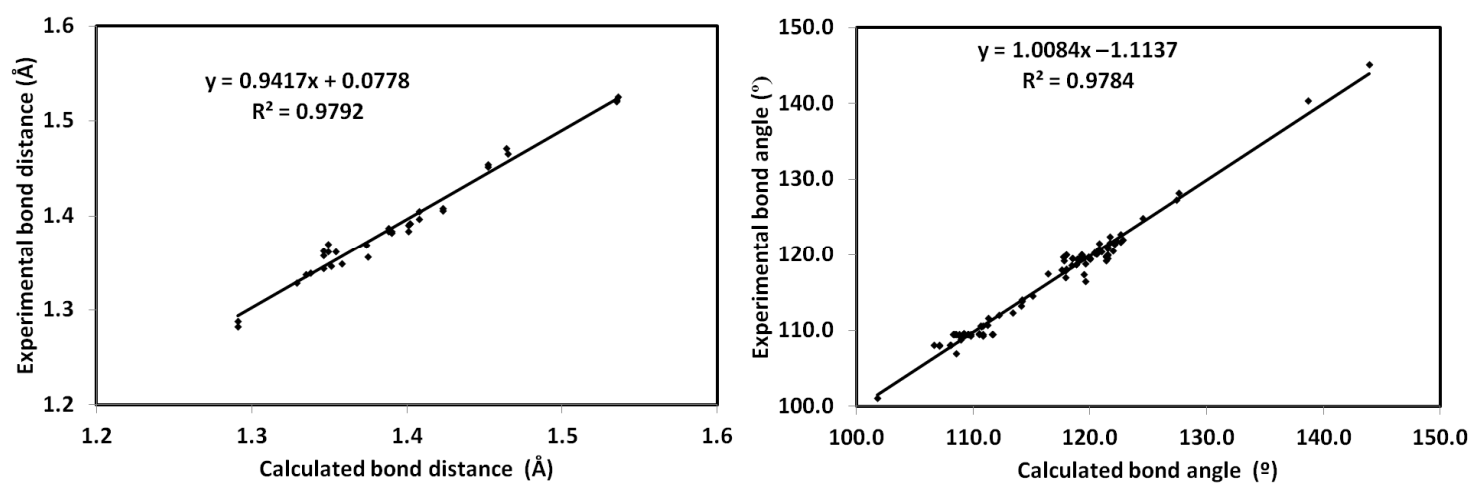

Figure 11. Correlations between the calculated and experimental geometric parameters. 
The studied system comprised CHNO skeleton where the oxygen and nitrogen atoms as well as the majority of carbon atoms are negatively charged (Figure 12). The morpholine oxygen atoms and the s-triazine $\mathrm{N}$-atoms have the highest negative charge. The studied compound is polar molecule (2.7591 Debye) and the dipole moment vector is shown in Figure 13 (left part). The red regions in molecular electrostatic potential reveal high electron density related to hydroxyl oxygen atoms and the aryl moieties. In contrast, the blue regions are related to the atomic sites with lowest electron density which is close to the $\mathrm{NH}$ protons.

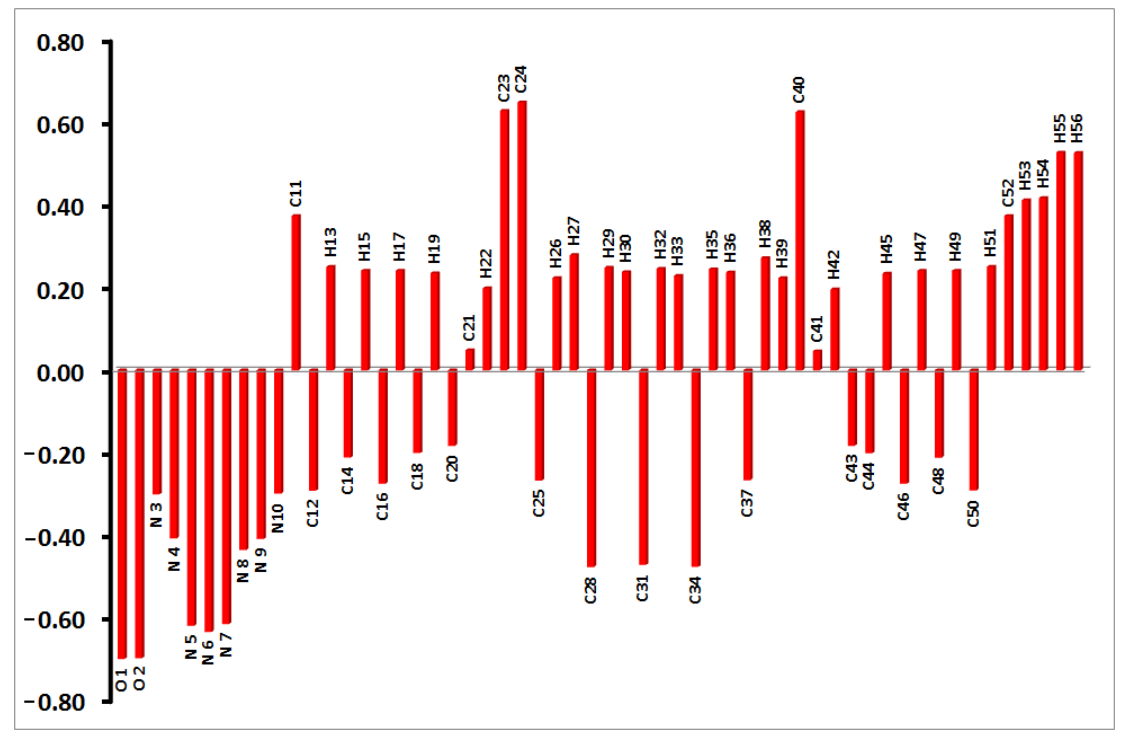

Figure 12. The natural atomic charges in 4 .
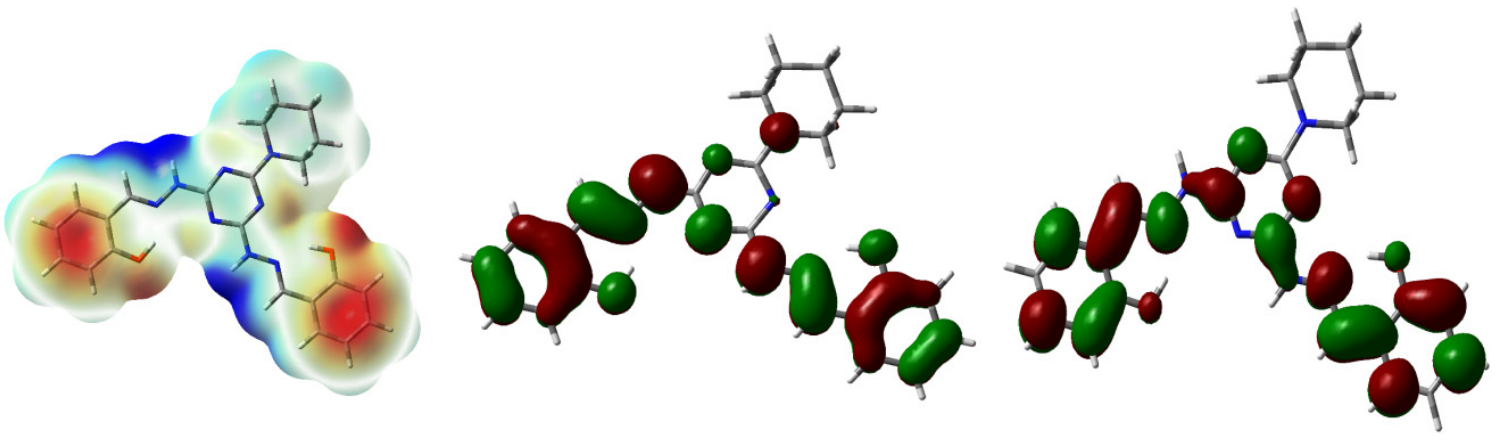

Figure 13. The MEP, HOMO, and LUMO of 4.

It is clear that the HOMO and LUMO levels are mainly distributed over the $\pi$-system of 4 (Figure 13). As a result, the $\mathrm{HOMO} \rightarrow \mathrm{LUMO}$ excitation is mainly a $\pi-\pi^{*}$ transition. The $\mathrm{HOMO} \rightarrow \mathrm{LUMO}$ excitation energy is $4.1536 \mathrm{eV}$. In addition, the reactivity indices include ionization potential $\left(\mathrm{I}=-\mathrm{E}_{\mathrm{HOMO}}\right)$, electron affinity $\left(\mathrm{A}=-\mathrm{E}_{\mathrm{LUMO}}\right)$, chemical potential $(\mu=-(I+A) / 2)$, hardness $(\eta=(I-A) / 2)$, as well as electrophilicity index $\left(\omega=\mu^{2} / 2 \eta\right)$ [42-47]. The calculated values of these descriptors are 5.5391, 1.3856, $-3.4624,4.1536$, and 1.4431, respectively.

\subsection{NBO Analysis}

The intramolecular charge transfer (IMCT) plays very important rule in the stability of compound. In this regard, the different IMCT processes $\left(\sigma-\sigma^{*}, \pi \rightarrow \pi^{*}, \mathrm{n} \rightarrow \sigma^{*}\right.$ and $\left.\mathrm{n} \rightarrow \pi^{*}\right)$ in 4 were calculated $[48,49]$ and their stabilization energies $\left(\mathrm{E}^{(2)}\right)$ are listed in Table 6. The maximum interaction energy due to the $\sigma-\sigma^{*}$ intramolecular charge transfer (IMCT) is $5.99 \mathrm{kcal} / \mathrm{mol}$ for the BD(1)N7-C23 $\rightarrow \mathrm{BD}^{*}(1) \mathrm{N} 9-\mathrm{C} 40$. The $\pi \rightarrow \pi^{*}, \mathrm{n} \rightarrow \pi^{*}$ and 
$\mathrm{n} \rightarrow \sigma^{*}$ IMCT processes have higher interaction energies with maximum $\mathrm{E}^{(2)}$ values of 48.26 , 71.52 , and $24.48 \mathrm{kcal} / \mathrm{mol}$ for the $\mathrm{BD}(2) \mathrm{N} 5-\mathrm{C} 24 \rightarrow \mathrm{BD}^{*}(2) \mathrm{N} 7-\mathrm{C} 23, \mathrm{LP}(1) \mathrm{N} 8 \rightarrow \mathrm{BD}^{*}(2) \mathrm{N} 5-$ $\mathrm{C} 24$, and $\mathrm{LP}(1) \mathrm{N} 3 \rightarrow \mathrm{BD}^{*}(1) \mathrm{O} 1-\mathrm{H} 56 \mathrm{IMCT}$, respectively. Interestingly, the presence of $\mathrm{LP}(1) \mathrm{N} 3 \rightarrow \mathrm{BD}^{*}(1) \mathrm{O} 1-\mathrm{H} 56$ and $\mathrm{LP}(1) \mathrm{N} 10 \rightarrow \mathrm{BD}^{*}(1) \mathrm{O} 2-\mathrm{H} 55$ IMCT processes with high $\mathrm{E}^{(2)}$ values of 24.48 and $23.08 \mathrm{kcal} / \mathrm{mol}$, respectively confirmed the stability of conformer 4 via intramolecular $\mathrm{O}-\mathrm{H} \ldots \mathrm{N}$ hydrogen bonding interactions.

Table 6. The IMCT processes and $\mathrm{E}^{(2)}$ values calculated using NBO method.

\begin{tabular}{|c|c|c|c|c|c|}
\hline $\mathrm{NBO}_{\mathbf{i}}$ & $\mathrm{NBO}_{j}$ & $E(2)$ & $\mathrm{NBO}_{\mathbf{i}}$ & $\mathrm{NBO}_{j}$ & $E(2)$ \\
\hline \multicolumn{3}{|c|}{$\sigma \rightarrow \sigma^{*}$} & \multicolumn{3}{|c|}{$\pi \rightarrow \pi^{*}$} \\
\hline BD(1)O1-H56 & $\mathrm{BD}^{*}(1) \mathrm{C} 11-\mathrm{C} 12$ & 5.06 & $\mathrm{BD}(2) \mathrm{N} 3-\mathrm{C} 21$ & $\mathrm{BD}^{*}(2) \mathrm{C} 18-\mathrm{C} 20$ & 7.87 \\
\hline BD(1)O2-H55 & $\mathrm{BD}^{*}(1) \mathrm{C} 50-\mathrm{C} 52$ & 5.02 & $\mathrm{BD}(2) \mathrm{N} 5-\mathrm{C} 24$ & $\mathrm{BD}^{*}(2) \mathrm{N} 7-\mathrm{C} 23$ & 48.26 \\
\hline $\mathrm{BD}(1) \mathrm{N} 5-\mathrm{C} 24$ & $\mathrm{BD}^{*}(1) \mathrm{N} 4-\mathrm{C} 23$ & 5.63 & $\mathrm{BD}(2) \mathrm{N} 6-\mathrm{C} 40$ & $\mathrm{BD}^{*}(2) \mathrm{N} 5-\mathrm{C} 24$ & 39.11 \\
\hline $\mathrm{BD}(1) \mathrm{N} 7-\mathrm{C} 23$ & $\mathrm{BD}^{*}(1) \mathrm{N} 9-\mathrm{C} 40$ & 5.99 & $\mathrm{BD}(2) \mathrm{N} 7-\mathrm{C} 23$ & $\mathrm{BD}^{*}(2) \mathrm{N}$ 6-C40 & 45.32 \\
\hline $\mathrm{BD}(1) \mathrm{C} 20-\mathrm{C} 21$ & $\mathrm{BD}^{*}(1) \mathrm{N} 3-\mathrm{N} 4$ & 5.22 & $\mathrm{BD}(2) \mathrm{N} 10-\mathrm{C} 41$ & $\mathrm{BD}^{*}(2) \mathrm{C} 43-\mathrm{C} 44$ & 7.88 \\
\hline \multirow[t]{7}{*}{$\mathrm{BD}(1) \mathrm{C} 41-\mathrm{C} 43$} & $\mathrm{BD}^{*}(1) \mathrm{N}$ 9-N10 & 5.20 & $\mathrm{BD}(2) \mathrm{C} 11-\mathrm{C} 12$ & $\mathrm{BD}^{*}(2) \mathrm{C} 14-\mathrm{C} 16$ & 25.09 \\
\hline & & & $\mathrm{BD}(2) \mathrm{C} 11-\mathrm{C} 12$ & $\mathrm{BD}^{*}(2) \mathrm{C} 18-\mathrm{C} 20$ & 17.00 \\
\hline & & & $\mathrm{BD}(2) \mathrm{C} 14-\mathrm{C} 16$ & $\mathrm{BD}^{*}(2) \mathrm{C} 11-\mathrm{C} 12$ & 17.55 \\
\hline & & & $\mathrm{BD}(2) \mathrm{C} 14-\mathrm{C} 16$ & $\mathrm{BD}^{*}(2) \mathrm{C} 18-\mathrm{C} 20$ & 24.64 \\
\hline & & & $\mathrm{BD}(2) \mathrm{C} 18-\mathrm{C} 20$ & $\mathrm{BD}^{*}(2) \mathrm{N} 3-\mathrm{C} 21$ & 24.97 \\
\hline & & & $\mathrm{BD}(2) \mathrm{C} 18-\mathrm{C} 20$ & $\mathrm{BD}^{*}(2) \mathrm{C} 11-\mathrm{C} 12$ & 21.73 \\
\hline & $\mathrm{n} \rightarrow \boldsymbol{\sigma}^{*}$ & & & $\mathbf{n} \rightarrow \pi^{*}$ & \\
\hline $\mathrm{LP}(1) \mathrm{O} 1$ & $\mathrm{BD}^{*}(1) \mathrm{C} 11-\mathrm{C} 20$ & 7.96 & $\mathrm{BD}(2) \mathrm{C} 18-\mathrm{C} 20$ & $\mathrm{BD}^{*}(2) \mathrm{C} 14-\mathrm{C} 16$ & 17.03 \\
\hline $\mathrm{LP}(1) \mathrm{O} 2$ & $\mathrm{BD}^{*}(1) \mathrm{C} 43-\mathrm{C} 52$ & 8.02 & $\mathrm{BD}(2) \mathrm{C} 43-\mathrm{C} 44$ & $\mathrm{BD}^{*}(2) \mathrm{N} 10-\mathrm{C} 41$ & 24.95 \\
\hline $\mathrm{LP}(1) \mathrm{N} 3$ & $\mathrm{BD}^{*}(1) \mathrm{O} 1-\mathrm{H} 56$ & 24.48 & $\mathrm{BD}(2) \mathrm{C} 43-\mathrm{C} 44$ & $\mathrm{BD}^{*}(2) \mathrm{C} 46-\mathrm{C} 48$ & 17.02 \\
\hline $\mathrm{LP}(1) \mathrm{N} 3$ & $\mathrm{BD}^{*}(1) \mathrm{N} 4-\mathrm{H} 54$ & 8.74 & $\mathrm{BD}(2) \mathrm{C} 43-\mathrm{C} 44$ & $\mathrm{BD}^{*}(2) \mathrm{C} 50-\mathrm{C} 52$ & 21.68 \\
\hline $\mathrm{LP}(1) \mathrm{N} 3$ & $\mathrm{BD}^{*}(1) \mathrm{C} 21-\mathrm{H} 22$ & 9.92 & $\mathrm{BD}(2) \mathrm{C} 46-\mathrm{C} 48$ & $\mathrm{BD}^{*}(2) \mathrm{C} 43-\mathrm{C} 44$ & 24.65 \\
\hline LP(1)N 5 & $\mathrm{BD}^{*}(1) \mathrm{N} 7-\mathrm{C} 23$ & 13.54 & $\mathrm{BD}(2) \mathrm{C} 46-\mathrm{C} 48$ & $\mathrm{BD}^{*}(2) \mathrm{C} 50-\mathrm{C} 52$ & 17.57 \\
\hline $\mathrm{LP}(1) \mathrm{N} 5$ & $\mathrm{BD}^{*}(1) \mathrm{N}$ 6-C24 & 12.09 & $\mathrm{BD}(2) \mathrm{C} 50-\mathrm{C} 52$ & $\mathrm{BD}^{*}(2) \mathrm{C} 43-\mathrm{C} 44$ & 17.07 \\
\hline $\mathrm{LP}(1) \mathrm{N} 6$ & $\mathrm{BD}^{*}(1) \mathrm{N} 5-\mathrm{C} 24$ & 11.84 & $\mathrm{BD}(2) \mathrm{C} 50-\mathrm{C} 52$ & $\mathrm{BD}^{*}(2) \mathrm{C} 46-\mathrm{C} 48$ & 25.10 \\
\hline $\mathrm{LP}(1) \mathrm{N} 6$ & $\mathrm{BD}^{*}(1) \mathrm{N} 7-\mathrm{C} 40$ & 13.29 & LP(2)O 1 & $\mathrm{BD}^{*}(2) \mathrm{C} 11-\mathrm{C} 12$ & 35.52 \\
\hline LP(1)N 7 & $\mathrm{BD}^{*}(1) \mathrm{N} 5-\mathrm{C} 23$ & 12.74 & $\mathrm{LP}(2) \mathrm{O} 2$ & $\mathrm{BD}^{*}(2) \mathrm{C} 50-\mathrm{C} 52$ & 35.53 \\
\hline LP(1)N 7 & $\mathrm{BD}^{*}(1) \mathrm{N}$ 6-C40 & 12.66 & $\mathrm{LP}(1) \mathrm{N} 4$ & $\mathrm{BD}^{*}(2) \mathrm{N} 3-\mathrm{C} 21$ & 31.38 \\
\hline LP(1)N10 & $\mathrm{BD}^{*}(1) \mathrm{O} 2-\mathrm{H} 55$ & 23.08 & $\mathrm{LP}(1) \mathrm{N} 4$ & $\mathrm{BD}^{*}(2) \mathrm{N} 7-\mathrm{C} 23$ & 53.44 \\
\hline LP(1)N10 & $\mathrm{BD}^{*}(1) \mathrm{C} 41-\mathrm{H} 42$ & 10.00 & $\mathrm{LP}(1) \mathrm{N} 8$ & $\mathrm{BD}^{*}(2) \mathrm{N} 5-\mathrm{C} 24$ & 71.52 \\
\hline \multirow[t]{2}{*}{ LP(1)N10 } & $\mathrm{BD}^{*}(1) \mathrm{N}$ 9-H53 & 8.82 & LP(1)N 9 & $\mathrm{BD}^{*}(2) \mathrm{N}$ 6-C40 & 52.75 \\
\hline & & & $\mathrm{LP}(1) \mathrm{N} 9$ & $\mathrm{BD}^{*}(2) \mathrm{N} 10-\mathrm{C} 41$ & 31.48 \\
\hline
\end{tabular}

\section{Conclusions}

The synthesis and X-ray structure of the new 2,2'-(6-(piperidin-1-yl)-1,3,5-triazine-2,4diyl)bis(hydrazin-2-yl-1-ylidene))bis(methanylylidene))diphenol giant $s$-triazine bis-Schiff base were presented. Among the suggested 17 conformers, 4 was found to be the most stable one in agreement with the reported X-ray structure. Generally, conformers with larger number of intramolecular $\mathrm{O}-\mathrm{H} \ldots \mathrm{N}$ hydrogen bonding interactions are the most stable. The presence of intramolecular $\mathrm{O}-\mathrm{H} \ldots \mathrm{N}$ hydrogen bonds was further revealed by NBO calculations. Using Hirshfeld calculations, the $\mathrm{O} \ldots \mathrm{H}, \mathrm{N} \ldots \mathrm{H}, \mathrm{C} \ldots \mathrm{H}, \mathrm{H} \ldots \mathrm{H}$, and $\mathrm{C} \ldots \mathrm{C}$ intermolecular contacts are the most important in the crystal stability. Their percentages were calculated to be $9.8,15.8,23.7,46.4$, and $1.6 \%$ from the whole contacts occurred in the crystal, respectively. MEP, HOMO, LUMO, dipole moment, and natural charges were also presented.

Supplementary Materials: The following are available online at https:/ /www.mdpi.com/article/ 10.3390/cryst11111418/s1, Table S1: The calculated and experimental bond distances and angles, Table S2: Bond lengths $[\AA]$ and angles $\left[^{\circ}\right]$ for 4, Table S3: Anisotropic displacement pa-rameters $\left(\AA^{2} \times 10^{3}\right)$ for 4 . The anisotropic displacement factor exponent takes the form: $-2 \mathrm{p}^{2}\left[\mathrm{~h}^{2} \mathrm{a}^{* 2} \mathrm{U}^{11}+\ldots\right.$ 
$+2 \mathrm{~h} \mathrm{k} \mathrm{a}^{*} \mathrm{~b}^{*} \mathrm{U}^{12}$ ], Table S4: Hydrogen coordinates $\left(\times 10^{4}\right)$ and iso-tropic displacement parameters $\left(\AA^{2} \times 10^{3}\right)$ for 4, Table S5: Torsion angles [ $\left.{ }^{\circ}\right]$ for 4 , Figure S1: ${ }^{1} \mathrm{H}$ and ${ }^{13} \mathrm{C}$ NMR spectra of 4 .

Author Contributions: Conceptualization, A.E.-F., S.M.S. and Z.M.A.; synthesis and characterization, A.E.-F. and Z.M.A.; X-ray crystal structure determination, M.H.; computational investigation, S.M.S.; writing original manuscript, A.E.-F., M.H., Z.M.A., M.I.A.-Z., A.B.B. and S.M.S.; revision and editing, A.E.-F., M.H., Z.M.A., M.I.A.-Z., A.B.B. and S.M.S. All authors have read and agreed to the published version of the manuscript.

Funding: Deanship of Scientific Research at King Saud University for funding (RGP-070).

Institutional Review Board Statement: Not applicable.

Informed Consent Statement: Not applicable.

Data Availability Statement: Not applicable.

Acknowledgments: The authors extend their appreciation to the Deanship of Scientific Research at King Saud University for funding this work through research group No (RGP-070).

Conflicts of Interest: The authors declare no conflict of interest.

\section{References}

1. Blotny, G. Recent applications of 2, 4, 6-trichloro-1, 3, 5-triazine and its derivatives in organic synthesis. Tetrahedron 2006, 62, 9507-9522. [CrossRef]

2. Rapoport, L.; Smolin, E. The Chemistry of Heterocyclic Compounds, Triazines; John Wiley \& Sons: Hoboken, NJ, USA, 2009.

3. Solankee, A.; Kapadia, K.; Ćirić, A.; Soković, M.; Doytchinova, I.; Geronikaki, A. Synthesis of some new S-triazine based chalcones and their derivatives as potent antimicrobial agents. Eur. J. Med. Chem. 2010, 45, 510-518. [CrossRef]

4. Gavade, S.N.; Markad, V.L.; Kodam, K.M.; Shingare, M.S.; Mane, D.V. Synthesis and biological evaluation of novel 2, 4, 6-triazine derivatives as antimicrobial agents. Bioorg. Med. Chem. Lett. 2012, 22, 5075-5077. [CrossRef]

5. Patel, R.V.; Patel, A.B.; Kumari, P.; Chikhalia, K.H. Synthesis of novel 3-(5-sulfanyl-1, 3, 4-oxadiazol-2-yl)-2H-chromen-2-one condensed s-triazinyl piperazines and piperidines as antimicrobial agents. Med. Chem. Res. 2012, 21, 3119-3132. [CrossRef]

6. Singh, U.; Bhat, H.; Gahtori, P. Antifungal activity, SAR and physicochemical correlation of some thiazole-1, 3, 5-triazine derivatives. J. Mycol. Med. 2012, 22, 134-141. [CrossRef]

7. Sharma, A.; Sheyi, R.; de la Torre, B.G.; El-Faham, A.; Albericio, F. s-Triazine: A Privileged Structure for Drug Discovery and Bioconjugation. Molecules 2021, 26, 864. [CrossRef]

8. Al Rasheed, H.H.; Malebari, A.M.; Dahlous, K.A.; Fayne, D.; El-Faham, A. Synthesis, Anti-proliferative Activity, and Molecular Docking Study of New Series of 1,3-5-Triazine Schiff Base Derivatives. Molecules 2020, 25, 4065. [CrossRef]

9. Kumar, A.; Srivastava, K.; Kumar, S.R.; Puri, S.; Chauhan, P.M. Synthesis of 9-anilinoacridine triazines as new class of hybrid antimalarial agents. Bioorg. Med. Chem. Lett. 2009, 19, 6996-6999. [CrossRef]

10. Pedrares, A.S.; Camina, N.; Romero, J.; Duran, M.L.; Vazquez, J.G.; Sousa, A. Electrochemical synthesis and crystal structure of cobalt(II), nickel(II), copper(II), zinc(II) and cadmium(II) complexes with 2-pyridinecarbaldehyde-(2'aminosulfonylbenzoyl)hydrazone. Polyhedron 2008, 27, 3391-3397. [CrossRef]

11. Sonmez, M.; Celebi, M.; Berber, I. Synthesis, spectroscopic and biological studies on the new symmetric Schiff base derived from 2,6-diformyl-4-methylphenol with N-aminopyrimidine. Europ. J. Med. Chem. 2010, 45, 1935-1940. [CrossRef] [PubMed]

12. Teoh, S.G.; Yeap, G.Y.; Loah, C.C.; Foong, L.W.; Teo, S.B. Inner coordination sphere tin(IV) complexes with some O,N,N-terdentate $\{\mathrm{N}$-(2-hydroxybenzaldehyde)-1-amino-2-phenyleneimine and N-(2-hydroxy-1-naphthaldehyde)-1-amino-2-phenyleneimine $\}$ and $\mathrm{O}, \mathrm{N}, \mathrm{N}, \mathrm{O}$-quadridentate $\left\{\mathrm{N}, \mathrm{N}^{\prime}\right.$-bis(2-hydroxybenzaldehyde)-1,2-phenylenediimine and $\mathrm{N}, \mathrm{N}^{\prime}$-bis(2-hydroxy-1-naphthaldehyde)1,2-phenylenediimine\} Schiff bases. Polyhedron 1997, 16, 2213-2221.

13. Pokhariyal, G.P.; Lal, B.K.; Rastogi, V. Synthesis, spectral and thermal studies of some divalent metal complexes with 8-acetyl-7hydroxy-4-methyl coumarrin oxime-hdrazone. Asian J. Chem. 1997, 9, 541-543.

14. Barbazan, P.; Carballo, R.; Covelo, B.; Lodeiro, C.; Lima, J.C.; Vazquez-Lopez, E.M. Synthesis, characterization, and photophysical properties of 2-hydroxybenzaldehyde [(1E)-1-pyridin-2-ylethylidene]hydrazone and Its Rhenium(I) complexes. Eur. J. Inorg. Chem. 2008, 2008, 2713-2720. [CrossRef]

15. Banerjee, S.; Mondal, S.; Chakraborty, W.; Sen, S.; Gachhui, R.; Butcher, R.J.; Slawin, A.M.Z.; Mandal, C.; Mitra, S. Interaction of boric acid with salicyl derivatives as an anchor group of boron-selective adsorbents. Eur. J. Org. Chem. 2008, 27, 2785-2790.

16. Ghavtadze, N.; Frohlich, R.; Würthwein, E.U. 2H-Pyrrole Derivatives from an Aza-Nazarov Reaction Cascade Involving Indole as the Neutral Leaving Group. Eur. J. Org. Chem. 2008, 2008, 3656-3667. [CrossRef]

17. Cornelissen, J.P.; Van Diemen, J.H.; Groeneveld, L.R.; Haasnoot, J.G.; Spek, A.L.; Reedijk, J. Synthesis and properties of isostructural transition-metal (copper, nickel, cobalt, and iron) compounds with $7,7^{\prime}, 8,8^{\prime}$-tetracyanoquinodimethanide(1-) in an unusual monodentate coordination mode. Crystal structure of bis(3,5-bis(pyridin-2-yl)-4-amino-1,2,4-triazole)bis(7,7' $, 8,8^{\prime}$ tetracyanoquinodimethanido) copper(II). Inorg. Chem. 1992, 31, 198-202. 
18. Kandil, F.; Chebani, M.K.; Al Zoubi, W. Synthesis of macrocyclic bis-hydrazone and their use in metal cations extraction. Org. Chem. 2012, 2012, 208284. [CrossRef]

19. Barakat, A.; El-Faham, A.; Haukka, M.; Al-Majid, A.M.; Soliman, S.M. s-Triazine Pincer Ligands: Synthesis of their Metal Complexes, Coordination Behavior, and Applications. App. Organomet. Chem. 2021, 35, e6317. [CrossRef]

20. Gui, M.D.; Zhang, R.H.; Yan, H.; Wang, H.M.; Chen, X.B.; Zhu, S.J. Synthesis and magnetic and catalytic properties of manganous isonicotinoyl hydrazone complexes. Synth. React. Inorg. Met. Org. Chem. 1998, 28, 1381-1391. [CrossRef]

21. Agarwal, S.K.; Jain, J.; Chand, S. Synthetic and antimicrobial studies of hexacoordinated ternary complexes of Mn(II) and Cu(II). Asian J. Chem. 2002, 14, 489-492.

22. Deepa, K.P.; Aravindakshan, K.K.; Suhara, F. Synthesis, characterization and antifungal studies of metal, complexes of benzoyland salicylylhydrazones of N-methylacetoacetanilide. Asian J. Chem. 2001, 13, 513-523.

23. Iskander, M.F.; El-Sayed, L.; Salem, N.M.H.; Haase, W.; Linder, H.J.; Foro, S. Synthesis, characterization and magnetochemical studies of some copper(II) complexes derived from N-salicylidene-n-alkanoylhydrazins: X-Ray crystal and molecular structure of bis [monochloro-( $\mu$-N-salicylidenemyristoylhydrazine) ono(-1)] dicopper(II). Polyhedron 2004, 23, 23-31. [CrossRef]

24. Lasri, J.; Haukka, M.; Al-Rasheed, H.H.; Abutaha, N.; El-Faham, A.; Soliman, S.M. Synthesis, structure and in vitro anticancer activity of Pd(II) complex of pyrazolyl-s-triazine ligand; A new example of metal-mediated hydrolysis of s-triazine pincer ligand. Crystals 2021, 11, 119. [CrossRef]

25. Al-Rasheed, H.H.; Malebari, A.M.; Dahlous, K.A.; El-Faham, A. Synthesis and Characterization of New Series of 1,3-5-Triazine Hydrazone Derivatives with Promising Antiproliferative Activity. Molecules 2020, 25, 2708. [CrossRef]

26. Gamez, P.; Reedijk, J. 1,3,5-Triazine-based synthons in supramolecular chemistry. Eur. J. Inorg. Chem. 2006, 2006, 29-42. [CrossRef]

27. Soliman, S.M.; El-Faham, A. Synthesis and structural DFT studies of Ni(II) and Co(II) complexes with s-triazine-based dicompartmental ligand. Polyhedron 2019, 165, 162-170. [CrossRef]

28. Demeshko, S.; Dechert, S.; Meyer, F. Anion $-\pi$ Interactions in a carousel copper(II)-triazine complex. J. Am. Chem. Soc. 2004, 126, 4508-4509. [CrossRef]

29. Ramírez, J.; Stadler, A.M.; Harrowfield, J.M.; Brelot, L.; Huuskonen, J.; Rissanen, K.; Allouche, L.; Lehn, J.M. Coordination architectures of large heavy metal cations $\left(\mathrm{Hg}^{2+}\right.$ and $\left.\mathrm{Pb}^{2+}\right)$ with bis-tridentate ligands: Solution and solid-state studies. Z. Anorg. Allg. Chem. 2007, 633, 2435-2444. [CrossRef]

30. Ramírez, J.; Stadler, A.M.; Brelot, L.; Lehn, J.M. Coordinative, conformational and motional behavior of triazine-based ligand strands on binding of $\mathrm{Pb}(\mathrm{II})$ cations. Tetrahedron 2008, 64, 8402-8410. [CrossRef]

31. Das, A.; Demeshko, S.; Dechert, S.; Meyer, F. A new triazine-based tricompartmental ligand for stepwise assembly of mononuclear, dinuclear, and 1D-polymeric heptacoordinate manganese(II)/azido complexes. Eur. J. Inorg. Chem. 2011, 2011, 1240-1248. [CrossRef]

32. Pavelek, L.; Ladányi, V.; Necâs, M.; Vallová, S.; Wichterle, K. Dioxouranium complexes with pentadentate s-triazine Schiff base ligands: Synthesis, crystal structure and optical properties. Polyhedron 2016, 107, 89-96. [CrossRef]

33. Hudson, M.J.; Harwood, L.M.; Laventine, D.M.; Lewis, F.W. Use of soft heterocyclic N-donor ligands to separate actinides and lanthanides. Inorg. Chem. 2013, 52, 3414-3428. [CrossRef]

34. Rikagu Oxford Diffraction; CrysAlisPro; Agilent Technologies Inc.: Yarnton, Oxfordshire, UK, 2020.

35. Sheldrick, G.M. SHELXT-Integrated space-group and crystal-structure determination. Acta Cryst. 2015, A71, 3-8. [CrossRef]

36. Sheldrick, G.M. Crystal structure refinement with SHELXL. Acta Cryst. 2015, C71, 3-8.

37. Hübschle, C.B.; Sheldrick, G.M.; Dittrich, B. ShelXle: A Qt graphical user interface for SHELXL. J. Appl. Cryst. 2011, 44, 1281-1284. [CrossRef] [PubMed]

38. Turner, M.J.; McKinnon, J.J.; Wolff, S.K.; Grimwood, D.J.; Spackman, P.R.; Jayatilaka, D.; Spackman, M.A. Crystal Explorer17 (2017) University of Western Australia. Available online: http:/ / hirshfeldsurface.net (accessed on 12 June 2017).

39. Frisch, M.J.; Trucks, G.W.; Schlegel, H.B.; Scuseria, G.E.; Robb, M.A.; Cheeseman, J.R.; Scalmani, G.; Barone, V.; Mennucci, B.; Petersson, G.A.; et al. GAUSSIAN 09; Revision A02; Gaussian Inc.: Wallingford, CT, USA, 2009.

40. Dennington, R., II; Keith, T.; Millam, J. (Eds.) GaussView; Version 4.1; Semichem Inc.: Shawnee Mission, KS, USA, 2007.

41. Reed, A.E.; Curtiss, L.A.; Weinhold, F. Intermolecular interactions from a natural bond orbital, donor-acceptor viewpoint. Chem. Rev. 1988, 88, 899-926. [CrossRef]

42. Foresman, J.B.; Frisch, M.J. Exploring Chemistry with Electronic Structure Methods, 2nd ed.; Gaussian: Pittsburgh, PA, USA, 1996.

43. Chang, R. Chemistry, 7th ed.; McGraw-Hill: New York, NY, USA, 2001.

44. Kosar, B.; Albayrak, C. Spectroscopic investigations and quantum chemical computational study of (E)-4-methoxy-2-[(ptolylimino) methyl] phenol. Spectrochim. Acta 2011, 78, 160-167. [CrossRef]

45. Koopmans, T.A. Ordering of wave functions and eigen energies to the individual electrons of an atom. Physica 1933, 1, 104-113. [CrossRef]

46. Parr, R.G.; Yang, W. Density-Functional Theory of Atoms and Molecules; Oxford University Press: New York, NY, USA, 1989.

47. Parr, R.G.; Szentpaly, L.V.; Liu, S. Electrophilicity index. J. Am. Chem. Soc. 1999, 121, 1922-1924. [CrossRef]

48. Joe, I.H.; Kostova, I.; Ravikumar, C.; Amalanathan, M.; Pînzaru, S.C. Theoretical and vibrational spectral investigation of sodium salt of acenocoumarol. J. Raman Spectrosc. 2009, 40, 1033-1038. [CrossRef]

49. Sebastian, S.; Sundaraganesan, N. The spectroscopic (FT-IR, FT-IR gas phase, FT-Raman and UV) and NBO analysis of 4Hydroxypiperidine by density functional method. Spectrochim. Acta A 2010, 75, 941-952. [CrossRef] [PubMed] 